\title{
Application of Different Rates and Frequencies of Rejuvenator for the Treatments of Brown Bast Syndrome on Hevea brasiliensis
}

N.H. Nik Hashyati' ${ }^{1}$ Z. Sulaiman ${ }^{1,2}$, M.A. Salisu', M.Y.A. Samad ${ }^{2,3}$, M.T.M. Mohamed ${ }^{1}$, Mohd Shafar Jefri Mokhtar ${ }^{1}$, Zarawi A.B. Ghani', Azwan Adinan ${ }^{4}$

10.18805/IJARe.AF-678

\begin{abstract}
Background: Brown bast is one of the most serious threats to natural rubber production. It is estimated that brown bast leads to an approximately $15-20 \%$ decrease in latex yield production. There is currently no effective method to control this problem and an effort to overcome this problem is in progress by the natural rubber producing countries.

Methods: This study evaluated the effect and the most suitable rate and frequency of Rejuvenator application to cure brown bast (latex dryness) and improve latex yield. The Rejuvenator treatment was applied to the selected tree with two different treatment frequencies (every 3 days and every 6 days) and three different Rejuvenator concentrations ( $5 \mathrm{~g} / \mathrm{L}, 10 \mathrm{~g} / \mathrm{L}$ and $15 \mathrm{~g} / \mathrm{L})$. The Rejuvenator was applied 5 times. Data on latex yield and brown bast cure were then recorded 1 month after the application of the last treatment. The treatments used were T1: No Rejuvenator, T2: $5 \mathrm{~g} / \mathrm{L}$ of Rejuvenator, T3: $10 \mathrm{~g} / \mathrm{L}$ of Rejuvenator, T4: $15 \mathrm{~g} / \mathrm{L}$ of Rejuvenator. Result: Of all the treatment used, T3 $(10 \mathrm{~g} / \mathrm{L})$ resulted in higher production of latex yield and Hevea bark nutrient concentration $(\mathrm{g} / \mathrm{t} / \mathrm{t})$ than control. It also gave the highest nutrient content in the bark tissue. The findings of this study reveal that the optimum concentration and frequency of Rejuvenator application were established at $10 \mathrm{~g} / \mathrm{L}$ every 6 days. More so, the findings explain that inadequate nutrients can be attributed to the brown bast syndrome in rubber plantation which can be prevented with the use of a rejuvenator to the tree's bark.
\end{abstract}

Key words: Brown bast syndrome, Hevea brasiliensis, Latex yield, Rubber.

\section{INTRODUCTION}

The rubber industry is the second most important commodity in Malaysia after oil palm. It provides direct employment to more than 200,000 smallholder families with the downstream manufacturing sector providing direct employment to more than 64,000 workers. In recent times, rubber is being planted in marginal areas, such as dry areas, due to increased demand (Salisu et al. 2020; Rukkhun et al., 2021). However, there is a recent threat to its production. A syndrome called the Brown bast, also known as tapping panel dryness, has resurfaced in many rubber plantations in Malaysia and other neighbouring rubber producing countries after many years. The first apparent symptom of the 'brown bast' disease is bark dryness, which had long been recognised.

Brown bast causes degeneration in the phloem tissue, which first affects the latificers, where latex coagulates and tyloses develop (outgrowths of parenchyma cells into laticifers). However, the exact cause of these abnormalities are yet to be determined (De Fay and Jacob 1989). Nandris et al. (2004) reported that brown bast contributes to $15-20 \%$ loss of annual rubber production with an incidence of 20$50 \%$ where productive trees are affected by brown bast. In another study, Qi et al. (2014) reported that around 14.75\% of rubber trees are harmed by tapping panel dryness. Some researchers have termed the syndrome a disease; however, no pathogen has been detected so far in association with
${ }^{1}$ Department of Crop Science, Faculty of Agriculture, 43400 UPM Serdang, Selangor, Malaysia.

${ }^{2}$ Institute Plantation Studies, 43400 UPM Serdang Selangor, Malaysia.

${ }^{3}$ Department of Soil Management, Faculty of Agriculture, 43400 UPM Serdang, Selangor, Malaysia.

${ }^{4}$ Malaysian Rubber Board, $47000 \mathrm{Sg}$. Buloh Selangor Malaysia.

Corresponding Author: Z. Sulaiman, Department of Crop Science, Faculty of Agriculture, 43400 UPM Serdang, Selangor, Malaysia. Email: zulkefly@upm.edu.my

How to cite this article: Hashyati, N.H.N., Sulaiman, Z., Salisu, M.A., Samad, M.Y.A., Mohamed, M.T.M., Mokhtar, M.S.J., Ghani, Z.A.B. and Adinan, A. (2022). Application of Different Rates and Frequencies of Rejuvenator for the Treatments of Brown Bast Syndrome on Hevea brasiliensis. Indian Journal of Agricultural Research. DOI: 10.18805/IJARe.AF-678.

Submitted: 16-07-2021 Accepted: 05-11-2021 Online: 06-01-2022

the brown bast condition Liyanage et al. (1983). Thus, it is more generally recognised as a physiological disorder of rubber tree bark.

On the other hand, some researchers believe that the syndrome is caused by excessive exploitation from repeated removal of latexes and which results in nutrient stress on the tissue of the bark that is being exploited. De Fay (1982) conducted an experiment where he induced dryness in clone 
GT1 rubber trees, which normally would have been tapped twice a week, by tapping them 6 times a day. The study showed that continued tapping of rubber tree brings symptoms of exhaustion. According to Seetha et al. (1987), some workers have suggested that water and nutrient stresses are important in the development of the brown bast. Sadly, there is inadequate literature on the cure for the brown bast syndrome. In 2016, the average productivity of rubber smallholders was low with a mean of $1380 \mathrm{~kg} / \mathrm{ha} /$ year.

One of the main reasons for this low land productivity was the incidence of tapping panel dryness or brown bast. A study by Margarita (2004) also found the incidence of brown bast to be as high as $32 \%$ in certain clones with an average of $15.80 \%$. Despite the setbacks caused by the brown bast syndrome, Malaysia is committed to positioning itself among competitors by targeting a total Gross National Income of RM 3.11 billion from the rubber industry by the year 2020.

The importance of rubber as one of the polymers naturally produced by plants cannot be over-emphasized, especially among the developing countries Salisu et al. (2013). More so, rubber has been recognised as one of the Entry Point Projects (EPPs) in the national key economic area (NKEA) in Malaysia. Consequently, Rejuvenator was formulated with the composition of macro and micronutrients to treat the Brown bast phenomenon. Thus, this study evaluates the potential effect and most suitable rate and frequency of the Rejuvenator application to improve the yield of rubber plants that are affected by the brown bast syndrome.

\section{MATERIALS AND METHODS}

This study was carried out at department of Crop Science, Universiti Putra Malaysia and rubber Smallholder field in Kuala Nal, Kuala Krai, Kelantan $\left(5.595077^{\circ} \mathrm{N}, 102.1564^{\circ} \mathrm{E}\right)$ with mature rubber trees of clone RRIM 2002 and rubber plants that had been exposed to brown bast disease. The study was carried out between January and August 2018. A total of 111 trees which represents $26.7 \%$ of the experimental area were infected by brown bast, $0.96 \%$ (4 trees) of the study sample showed stunted growth and $11.8 \%$ (49 trees) died. A total of 251 trees which represents $60.48 \%$ were under tapping. The incidence of brown bast in this study is $26.7 \%$. Bark samples from healthy and brown bast affected trees were collected for treatment. The treatment consists of treatment frequencies and rates of the Rejuvenator concentration as $\mathrm{T} 1=$ control, $\mathrm{T} 2=5 \mathrm{~g} / \mathrm{L}, \mathrm{T} 3=10 \mathrm{~g} / \mathrm{L}, \mathrm{T} 4=15$ $\mathrm{g} / \mathrm{L}$. The Rejuvenator crystal (a commercial product comprise macro and micro nutrients) was weighed and placed in a container. Then, distilled water was added to bring the mixture up to $1 \mathrm{~L}$. Then, the mixture was stirred to make sure the Rejuvenator crystal completely dissolved.

The solution was then applied to the bark of the selected affected tree from $1 \mathrm{~m}$ above the ground. The treatment application was carried out every 3 days and every 6 days for 5 weeks. Thereafter, the treated trees were tapped one week after a total of five applications of the solution. Data on latex yield were recorded from the treated tree for 6 months and a sample bark from the treated trees was collected for nutrient analysis. The percentage of brown bast cured was measured by using a standard measuring tape on the tapping panel and calculated as follow:

$$
\% \text { of cure }=\frac{\begin{array}{l}
\text { Total length of } \\
\text { tapping panel }
\end{array}-\begin{array}{c}
\text { Length of cured } \\
\text { tapping panel }
\end{array}}{\text { The total length of the tapping panel }} \times 100
$$

Bark tissue analysis was carried out to determine the nutrient concentration and its effect on the rubber plant. The bark samples were collected and oven-dried at $65^{\circ} \mathrm{C}$ for 48 hours. Thereafter, it was weighed to constant weight. The foliar analysis was carried out according to the rubber industry foliar sampling techniques as described by Adekunle (2014). The samples were analyzed for N, P and $\mathrm{K}$ with Auto Analyser, while $\mathrm{Mg}$, $\mathrm{Ca}$ and $\mathrm{Fe}$ were analysed with Atomic Absorption Spectrometer (AAS) (Perkin Elmer, Model AAS 3110) image analysis.

The immune stained slides were imaged using Nikon microscope (80i) with photographic unit. The images were evaluated for presence of Brucella which was visualized by presence of brown coloured DAB reaction.

\section{Statistical analysis}

The statistical analysis system software version 9.4 (SAS Institute, North Carolina State University, USA) was used to analyze all data using the analysis of variance (ANOVA). The mean separations were compared using the least significant difference (LSD) at a $5 \%$ level.

\section{RESULTS AND DISCUSSION}

The result showed that the yield from different rates and frequencies of Rejuvenator application produced a similar latex yield as the healthy trees. This indicates that the Rejuvenator treatment at the optimum rate (T3: $10 \mathrm{~g} / \mathrm{L})$ can improve the latex yield of brown bast affected trees since the treated trees gave the same result as the healthy tree (control). This is supported by Lalani (2000) who reported that an increase in the latex yield due to fertiliser application can have a direct effect on girth size, growth of bark, bark renewal and canopy maintenance. Phosphorus is one of the most common nutrients for growth and development Boukhalfa-Deraoui (2021). This is similar to the result of a study conducted by Tiva et al. (2016) which pointed out that improved latex yield and plant physiological condition change due to fertilisation. Global population growth, soil nutrient deterioration and climate change have all led to a decline in the quality and quantity of cultivated plantation land Oladosu et al., (2021).

Furthermore, Tiva et al. (2016) reported that after 4 years of fertiliser application, the treatment with fertiliser showed a significant difference in rubber yield ( $\mathrm{g} /$ tree) but which could be increased by $10 \%$. The results of the latex 
yield in selected months are presented in Table 1. Data on latex between March and May were not recorded being the wintering period when most of the trees lose their leaves and have minimal photosynthetic activity and consequently, a very low latex production. However, the latex yield production between June and September showed improvement in the production of latex due to the completeness of leaf formation. The results of the nutrient analysis on nitrogen $(\mathrm{N})$, phosphorus $(\mathrm{P})$, potassium $(\mathrm{K})$, magnesium $(\mathrm{Mg})$, calcium (Ca) and ferrum (Fe) over 5 months after the Rejuvenator treatment are presented in Table 2.

There was no interaction between the different frequencies and concentrations of Rejuvenator application on nutrient content since the $P$-value is greater than $\alpha=0.05$. The different frequencies, which were 6 days and 3 days' application, had no significant effect $(P>0.05)$ on the percentage of nutrient content in the bark samples. The nutrient concentrations in the plants increased with the increase in the doses of Rejuvenator. However, the nutrient concentrations among the Rejuvenator treatments were statistically similar but higher than the control. With a dose of the Rejuvenator as in the treatment T3 $(10 \mathrm{~g} / \mathrm{L})$, the percentage of all the nutrient contents were significantly different from the control (T1: $0 \mathrm{~g} / \mathrm{L})$ which recorded the lowest mean values. This indicates that the Rejuvenator treatment had a positive impact on the brown bast affected tree compared to control. The Rejuvenator treatment application probably increased the nutrients in the brown bast affected tree due to the availability of micro and macronutrient in the treatment. This is in line with the study conducted by Hashim et al. (2018) which observed that the physiological disorder of brown bast could have been due to the deficiency of nutrients or trace elements. The essential elements for plant development in relatively high proportions are nitrogen, phosphorus and potassium Krishna et al., (2020).

Table 1: Effect of frequency and concentration of Rejuvenator application on latex yield for 6 months.

\begin{tabular}{|c|c|c|c|c|c|c|}
\hline Latex yield & Jan & Feb & Jun & July & Aug & Sept \\
\hline \multicolumn{7}{|l|}{ Frequency } \\
\hline Three days & $2.613^{a}$ & $4.108^{a}$ & $1.263^{\mathrm{a}}$ & $1.267^{\mathrm{a}}$ & $2.908^{a}$ & $2.467^{b}$ \\
\hline Six days & $4.046^{\mathrm{a}}$ & $4.819^{\mathrm{a}}$ & $2.264^{\mathrm{a}}$ & $2.415^{\mathrm{a}}$ & $1.966^{\mathrm{a}}$ & $3.592^{\mathrm{a}}$ \\
\hline Critical value (LSD) & 1.722 & 1.493 & 0.782 & 1.201 & 0.629 & 1.084 \\
\hline \multicolumn{7}{|c|}{ Rejuvenator concentration (g/L) } \\
\hline T1: 0 (healthy tree) & $3.330^{\mathrm{a}}$ & $4.462^{\mathrm{a}}$ & $1.763^{\mathrm{a}}$ & $1.840^{\mathrm{a}}$ & $2.438^{a}$ & $3.030^{\mathrm{a}}$ \\
\hline T2: 5 & $1.923^{a}$ & $3.418^{\mathrm{a}}$ & $0.932^{\mathrm{a}}$ & $1.042^{\mathrm{a}}$ & $1.113^{\mathrm{a}}$ & $1.430^{\mathrm{a}}$ \\
\hline T3: 10 & $4.297^{a}$ & $5.017^{a}$ & $2.347^{a}$ & $2.385^{a}$ & $3.187^{a}$ & $3.995^{\mathrm{a}}$ \\
\hline T4: 15 & $3.768^{a}$ & $4.958^{\mathrm{a}}$ & $2.347^{a}$ & $2.097^{a}$ & $3.008^{a}$ & $3.663^{\mathrm{a}}$ \\
\hline Critical value (LSD) & 7.954 & 5.710 & 4.694 & 4.961 & 5.940 & 7.278 \\
\hline
\end{tabular}

Means values followed by the same letter in the same column are not significantly different at $P<0.05$, based on the least significant difference test (LSD).

Table 2: Effect of frequency and concentration of Rejuvenator application on nutrient contents in the bark sample.

\begin{tabular}{|c|c|c|c|c|c|c|}
\hline Factors & $\mathrm{N}(\%)$ & $\mathrm{P}(\%)$ & $\mathrm{K}(\%)$ & $\mathrm{Mg}(\%)$ & $\mathrm{Ca}(\%)$ & $\mathrm{Fe}(\%)$ \\
\hline \multicolumn{7}{|l|}{ Frequency } \\
\hline Three days & $0.054^{a}$ & $0.173^{a}$ & $0.545^{\mathrm{a}}$ & $0.112^{\mathrm{a}}$ & $1.111^{a}$ & $0.039^{a}$ \\
\hline Six days & $0.055^{\mathrm{a}}$ & $0.179^{a}$ & $0.553^{a}$ & $0.122^{\mathrm{a}}$ & $1.076^{a}$ & $0.038^{a}$ \\
\hline Critical value (LSD) & 0.016 & 0.0182 & 0.131 & 0.039 & 0.177 & 0.011 \\
\hline \multicolumn{7}{|l|}{ Rejuvenator concentration (g/L) } \\
\hline T1: 0 (brown bast affected tree) & $0.036^{b}$ & $0.139^{b}$ & $0.414^{b}$ & $0.072^{\mathrm{b}}$ & $0.897^{b}$ & $0.032^{b}$ \\
\hline T2: 5 & $0.060^{\mathrm{a}}$ & $0.183^{a}$ & $0.553^{\mathrm{ab}}$ & $0.121^{\mathrm{ab}}$ & $1.158^{\mathrm{a}}$ & $0.046^{a}$ \\
\hline T3: 10 & $0.064^{a}$ & $0.188^{a}$ & $0.651^{\mathrm{a}}$ & $0.137^{a}$ & $1.176^{\mathrm{a}}$ & $0.038^{a b}$ \\
\hline $\mathrm{T} 4: 15$ & $0.059^{a}$ & $0.193^{a}$ & $0.579^{a b}$ & $0.137^{a}$ & $1.143^{\mathrm{a}}$ & $0.038^{a b}$ \\
\hline Critical value (LSD) & 0.008 & 0.013 & 0.195 & 0.049 & 0.188 & 0.012 \\
\hline Variable & Probability & & & & & \\
\hline Freq $(F)$ & $0.712^{\text {ns }}$ & $0.184^{\mathrm{ns}}$ & $0.865^{\mathrm{ns}}$ & $0.413^{\text {ns }}$ & $0.456^{\mathrm{ns}}$ & $0.673^{\text {ns }}$ \\
\hline Conc (C) & $>.0001^{*}$ & $>.0001^{*}$ & $0.023^{*}$ & $0.005^{*}$ & $0.002^{*}$ & $0.043^{*}$ \\
\hline $\mathrm{F}^{*} \mathrm{C}$ & $0.255^{\mathrm{ns}}$ & $0.133^{\text {ns }}$ & $0.930^{\mathrm{ns}}$ & $0.421^{\mathrm{ns}}$ & $0.837^{\text {ns }}$ & $0.788^{\text {ns }}$ \\
\hline
\end{tabular}

For each frequency and concentration, the means values followed by the same letter in the same column are not significantly different at $\mathrm{P}<0.05$, based on the least significant difference test (LSD).

Notes: * ${ }^{*}$ Significant difference at $\alpha=0.05$

${ }^{n s}=$ No significant difference at $\alpha=0.05$. 


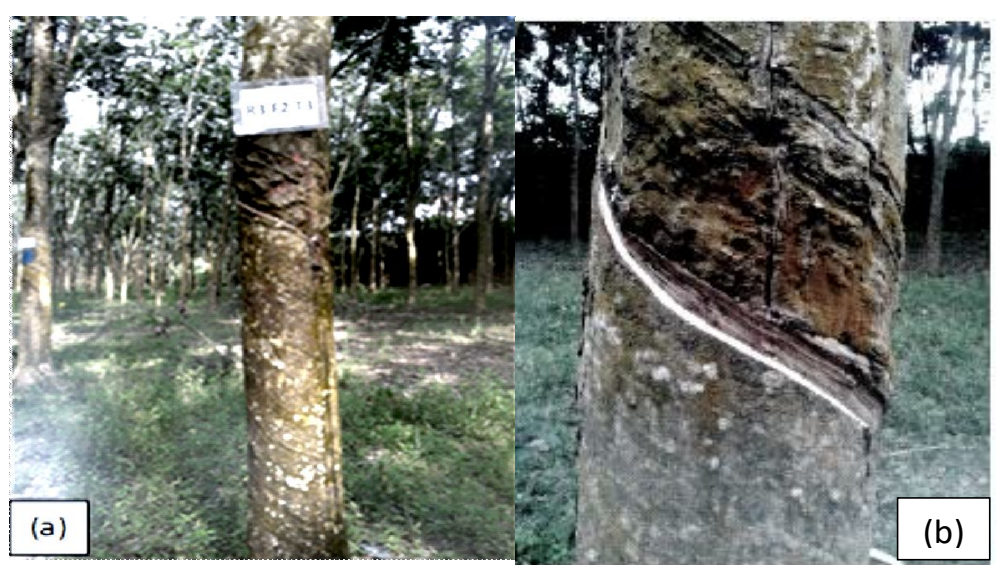

Fig 1: (a) Brown bast affected tree before the Rejuvenator treatment application with $5 \mathrm{~g} / \mathrm{L}$ concentration for every 6 days. (b) 3 months after the Rejuvenator treatment application, about $100 \%$ of latex comes out from the tapping panel.

The percentage of brown bast cured after the application of different rates and frequencies of Rejuvenator treatment are shown in Table 3. There was a significant difference between control and other different rates of Rejuvenator. However, there were no significant differences among the different Rejuvenator concentration rates T2 (5 g/L), T3 (10 $\mathrm{g} / \mathrm{L})$ and T4 (15 g/L) with a mean percentage of brown bast cure of $51.6 \%, 86.7 \%$ and $63.3 \%$, respectively. This indicates that treatment Rejuvenator concentration at the rate of 10 $\mathrm{g} / \mathrm{L}$ (T3) can positively cure a brown bast affected tree. The result presented in Table 4 shows that 9 trees which account for $50 \%$ were treated and cured of brown bast in the range $75 \%-100 \%, 5$ trees which account for $27.8 \%$ were treated and cured of brown bast in the range $50-75 \%$, just 1 tree was treated and cured of brown bast in the range $25-50 \%$ and only 3 trees were cured in the range $0-25 \%$.

The effect of the Rejuvenator was shown in Fig 1. According to Thomson et al. (2005), the number of trees having more than $75 \%$ of brown bast intensity takes time to cure due to the age of the tree and the tapping progress. The symptoms of brown bast in terms of morphological features and nature of latex production are complicated and shown as partial dryness, full dryness, dryness with bark out-growth and bark cracks (Senevirathna, 2006). Therefore, the fluctuation of the percentage of brown bast cured with time is expected because of the differences in the rates of onset and the recovery of dry trees with time. Probably, the high intensity of brown bast needs more time in Rejuvenator treatment to fully recover. Optimum rates and frequencies of the Rejuvenator treatment on brown bast affected trees appear to have a similar production of latex yield from healthy rubber trees. The application of the Rejuvenator treatment demonstrated good performance based on the percentage of nutrient status in the bark of the rubber tree and increased the percentage of trees cured.

The experiment revealed the suitability of the Rejuvenator application at different rates and frequencies where $10 \mathrm{~g} / \mathrm{L}$ of Rejuvenator concentration with 6 days' application is considered the optimum rate and frequency.
Table 3: Effect of frequency and concentration of the Rejuvenator application on the percentage of the cured plant from brown bast.

\begin{tabular}{lc}
\hline Factors & Cure of brown ba \\
\hline Frequency & \\
Three days & $41.667^{\mathrm{a}}$ \\
Six days & $59.167^{\mathrm{a}}$ \\
Critical value (LSD) & 6.2103 \\
Rejuvenator concentration (g/L) & \\
T1: 0 & $0.000^{\mathrm{b}}$ \\
T2: 5 & $51.670^{\mathrm{a}}$ \\
T3: 10 & $86.670^{\mathrm{a}}$ \\
T4: 15 & $63.330^{\mathrm{a}}$ \\
Critical value (LSD) & 43.088
\end{tabular}

Means values followed by the same letter in the same column are not significantly different at $\mathrm{P}<0.05$, based on the least significant difference test (LSD).

Table 4: Classification of the percentage of brown bast cured by Rejuvenator treatment.

\begin{tabular}{lc}
\hline Percentage & No. of tree \\
\hline $100 \%-75 \%$ & 9 \\
$75 \%-50 \%$ & 5 \\
$50 \%-25 \%$ & 1 \\
$25 \%-0 \%$ & 3 \\
\hline
\end{tabular}

The treated trees $(n=18)$, using Rejuvenator treatment at $5 \mathrm{~g} / \mathrm{L}, 10$ $\mathrm{g} / \mathrm{L}$ and $15 \mathrm{~g} / \mathrm{L}$ with frequencies of 3 days and 6-day intervals. Application of Different Rates and Frequencies of Rejuvenator.

Though higher rates (10 $\mathrm{g} / \mathrm{L}$ and $15 \mathrm{~g} / \mathrm{L})$ can be used, the $10 \mathrm{~g} / \mathrm{L}$ is enough as there is no significant difference in the production of latex yield with higher rates. The brown bast syndrome on rubber trees is considered economically important as it causes significant damages and affects latex yield production. Therefore, the application of Rejuvenator treatment on brown bast affected trees can be used by smallholders due to its potential effect as found in this study. 


\section{CONCLUSION}

Brown bast has been identified as one of the major physiological syndromes that cause great loss to rubber plantations. The application of Rejuvenator has shown positive results in its ability to control the syndrome in rubber, especially during an intensive tapping period. The percentage of all nutrient contents used in this study is significantly different from the control with the lowest latex yield and dose the Rejuvenator as in the treatment T3 (10 $\mathrm{g} / \mathrm{L})$. This shows that the Rejuvenator treatment has a positive effect on brown bast affected rubber trees. Its usage also boosted the highest nutrients in the bark tissue. The optimal concentration and duration of Rejuvenator application were determined to be $10 \mathrm{~g} / \mathrm{L}$ at six days' interval. Inadequate nutrients can cause brown bast syndrome in rubber plantation which can be avoided by applying a Rejuvenator to the tree's bark based on the recommended rate and the frequency application should be followed during tapping period.

\section{ACKNOWLEDGEMENT}

The authors would like to thank University Putra Malaysia for the grant is supporting the research study. We equally thank the staff of the Malaysia Rubber Board and smallholders at Kuala Nal, Kuala Krai, Kelantan for their support during the data collection.

\section{REFERENCES}

Adekunle, S.M. (2014). Influence of fertilizer rates on growth of selected immature rubber (Hevea brasiliensis Muell. arg) clones grown on two soil series. Master's Thesis, Universiti Putra Malaysia. Serdang, Malaysia.

Boukhalfa-Deraoui, N., Hanifi-Mekliche, L. and Mekliche, A. (2021). Response of wheat to foliar and soil $\mathrm{P}$ fertilization on grain yield and phosphorus use efficiency in Southeastern Algeria. Indian Journal of Agricultural Research. 55: 99104.

De Fay, E. (1982). Kinetics of the induction of dryness in Hevea brasiliensis. General Review of Rubbers and Plastics. 59: $185-188$.

De Fay, E. and Jacob, J.L. (1989). Symptomatology, Histological and Cytological Aspects. In: Physiology of Rubber Tree Latex. [J. d'Auzac, J. Jacob and H. Chrestin (Eds.)], Chemical Rubber Company Press, Florida. pp. 407-428.

Hashim, N.H.N., Sulaiman, Z., Mohamed, M.T.M. and Samad, M.Y.A. (2018). Overview of brown bast syndrome of Hevea brasiliensis. Pertanika Journal of Scholarly Research Reviews. 4: 25-30.

Krishna, K.V., Deepthi, C.H., Reddy, M.D., Raju, P.S. and Pal, A. (2020). Effect of nitrogen and phosphorus levels on growth and yield of finger millet [Eleusine coracana L.) during summer. Indian Journal of Agricultural Research. 54: 227-231.

Lalani, S. (2000). Economic and Efficiency of Fertilizer Utilization in Mature Rubber. Bulletin of the Rubber Research Institute of Sri Lanka. 42: 11-24.
Tiva, L.K., Locate, R., Chan, C., Sopheaveasna, M. and Gohet, E. (2016). Effects of fertilization on latex yield potential and physiological parameters of clone PB 217 in Cambodia. Proceeding Seminar Cambodia Rubber Research Institute and International Rubber Research and Development Board Conference. 2016, Siem Reap, Cambodia. pp. 46-48.

Liyanage, A.S., Peries, O.S., Liyanage, N.I.S., Irugalbandara, Z.E. and Wetta S.J.L.P. (1983). Annual. Rev. Rubber Research Institute Sri Lanka. pp. 55-56.

Margarita, C. (2004). Control of Brown Bast in Organic Rubber Cultivation. [Paper presentation]. Proceeding International Workshop on Tapping Panel Dryness, 2004 Rubber Research Institute of India. Kottayam, Kerala, India. pp. 73-75.

Salisu, M.A., Zulkefly, S., Ridzwan, C.R., Samad, M.Y.A., Norhanizan, U., Yusuff, O. and Paiman. (2020). Water use efficiency, plant growth and vegetative traits of rubber (Hevea brasiliensis) seedlings grown using different growing media and water levels. Australian Journal of Crop Science. 14: 1497-1505. DOI: 20.14.09.p.2643.

Nandris, D., Moreau, R., Pellegrin, F., Chrestin, H., Abina, J. and Angui, P. (2004). Rubber tree (Hevea brasiliensis) bark necrosis syndrome: II. First comprehensive report on causal stresses. Plant Disease. 88: 1047 -1047.

Oladosu, Y., Rafii, M.Y., Arolu, F., Chukwu, S.C., Salisu, M.A., Olaniyan, B.A. and Muftaudeen, T.K. (2021). Genetic diversity and utilization of cultivated eggplant germplasm in varietal improvement. Plants. 10: 1714.

Qi, D.L., Zhou, J.N., Xie, G. S. and Wu, Z.X. (2014). Studies on rubber (Hevea brasiliensis) trees exist plant type after planting and available tapping tree of rubber plantation in China. American Journal of Plant Sciences. 5: 3017-3021.

Rukkhun, R., Khongdee, N., lamsaard, K., Mawan, N., Sainoi, T. and Sdoodee, S. (2021). Latex diagnosis at the whole trunk level under different tapping systems in youngtapping rubber trees. Indian Journal of Agricultural Research. 55: 55-66.

Salisu, M., Daud, N. and Ahmad, I. (2013). Influence of fertilizer rates and soil series on growth performance of natural rubber (Hevea brasiliensis) latex timber clones. Australian Journal of Crop Science. 7: 1998- 2004.

Seetha, I.W., Yapa, P.A.J. and Thusini V.W.D.S. (1987). Accumulation of free proline in bark and latex of Hevea brasiliensis affected by brown bast. Journal of Rubber Research Institute of Sri Lanka. 67: 9-17.

Senevirathna, A.M.W.K (2006). Identification of physical factors affecting tapping panel dryness (TPD) of rubber (Hevea brasiliensis) and some biochemical changes at the onset of tapping panel dryness. Rubber Research Institute of Sri Lanka, Terminal Report CARP Project. pp. 67.

Thomson, A., Jacob, M., Srinivas, P. and Kuruvilla, J.C. (2005). Incidence of Tapping Panel Dryness (TPD) on Popular Rubber Clones in Southern Rubber Growing Region of India [Paper presentation]. Proceeding International Workshop on Tapping Panel Dryness 2005. Rubber Research Institute of India, Kottayam, Kerala, India. pp. 51-54. 